\title{
The Effectiveness of Trade for Trade Segment as a Surveillance Effort to Prevent Price Manipulation: Evidence from India
}

\author{
Kanaiyalal Shantilal $\operatorname{Parmar}^{1} \&$ Chakrapani Chaturvedula ${ }^{2}$ \\ ${ }^{1}$ Assistant Professor(Finance and Accounting), IBS Hyderabad, The ICFAI Foundation for Higher Education, (A \\ Deemed-to-be-University under Section 3 of the UGC Act, 1956), 156/157, Donthanapally, Shankarapalli Road, \\ Hyderabad - 501 203,Telangana State, India \\ ${ }^{2}$ Professor (Finance and Accounting), Institute of Management Technology, Hyderabad, Survey No. 38, Cherlaguda \\ Village, Shamshabad Mandal, RR District, Telangana State, Hyderabad - 501218, India \\ Correspondence: Chakrapani Chaturvedula, Professor (Finance and Accounting), Institute of Management \\ Technology, Hyderabad, Survey No. 38, Cherlaguda Village, Shamshabad Mandal, RR District, Telangana State, \\ Hyderabad - 501218, India
}

Received: July 5, 2016

Accepted: November 23, 2016

Online Published: December 6, 2016

doi:10.5430/afr.v6n1p9

URL: http://dx.doi.org/10.5430/afr.v6n1p9

\begin{abstract}
Indian Stock Exchanges use trade for trade segment as part of surveillance activity to restrict the unwanted growth in prices to safeguard the interest of the investors. This paper studies the impact of the announcement to shift securities to trade for trade segment on stock returns and volatility of the stock returns using event study methodology. It was found that the securities have generated exorbitant positive average abnormal returns during 30 days in the pre event period, which led the exchanges to shift these stocks to trade for trade segment. The event is found to be significantly impacting average abnormal returns during 30 days in the post event period showing the negative price reaction. Also volatility of the stocks returns is found to be increasing post the announcement.
\end{abstract}

Keywords: Market microstructure, Price manipulation, Market surveillance, Trade for trade segment, Capital market, Event study methodology

\section{JEL Classification: G1, G2.}

\section{Introduction}

Manipulative activities are likely to have adverse consequences in terms of attracting new listings / investors to, and retaining existing listings / investors in, a marketplace. The regulators across the globe have developed appropriate regulations and invested in security market surveillance. Understanding the effectiveness of security market surveillance departments should help investors and companies to gain confidence in a marketplace (Cumming and Johan (2008)).

Shifting of stocks to trade for trade segment with $5 \%$ price band is a part of surveillance mechanism adopted by the stock exchanges in India (Note 1). When a stock is shifted to the trade for trade segment with 5\% price bands, selling/ buying of shares in that scrip results into giving / taking delivery of shares at the gross level and no intraday netting off facility is permitted. Trade to trade settlement is a segment where shares can be traded only for compulsory delivery basis. The idea is to discourage intraday speculation. Thus trade for trade segment is related with trading restriction as well as price bands. Prior research has been done for analysing the impact of price bands on Indian and foreign markets (Kim and Rhee (1997) Kennerh Kim (2001) and Nath (2003)). However, trade for trade segment also involves an additional characteristic of trading restriction. We find no research examining the impact of shifting securities to trade for trade segment on stock returns and volatility of the stock returns.

Our objective is to examine the impact of the announcement to shift securities to trade for trade segment on stock returns and volatility of the stock returns using event study methodology. We find that securities have generated exorbitant positive average abnormal returns during 30 days in the pre event period, which led the exchanges to shift these stocks to trade for trade segment. The event is found to be significantly impacting average abnormal returns during 30 days in the post event period showing the negative reaction of stocks returns. Also volatility of the stocks returns is found to be increasing post the announcement. 
Rest of the paper is organised as follows. Section 2 discusses motivation and implications of the study. Section 3 details existing literature. Research gaps and research objectives are articulated in section 4. Section5 formulates hypotheses of the study. Section 6 outlines research methodology and data. Results are discussed in section 7. Salient findings and conclusions are given in section 8 . Section 9 indicates limitations of the study and avenues for further research.

\section{Motivation and Implications of the Study}

\subsection{Motivation of the Study}

Harris (1997) argues that if the regulators and exchanges fail to adopt price bands to control the market crashes, public would hold them responsible, notwithstanding whether the price bands would or even could have made a difference. In the other case, if they fail to adopt price bands and the market does not crash, nobody would credit them for saving costs the price bands may impose upon the market. If they adopt price bands they are not blamed whether the crash occurs or not. For, people would credit them for preventing the crash or if the crash occurs then people would learn that the crash cannot be prevented. Therefore the regulators and exchanges should adopt the market surveillance mechanisms under all conditions.

Further, the effectiveness of surveillance activity has an impact on prospective investors and companies in terms of choosing the market to operate in (Cumming and Johan (2008)). If the surveillance is not effective, prospective investors may choose to invest more on zero / low risk markets, such as government bonds and bank deposits. Further, companies may raise funds from debt market or other stock exchanges where surveillance is effective. Thus it is necessary for the stock exchanges not only to invest in market surveillance activity, but also to review its effectiveness periodically. Surprisingly, we did not find any study which addresses the question whether shifting stocks to trade for trade segment which is a part of surveillance effort is effective to control prevent price manipulation in India.

This has motivated us to study both the elements of trade for trade segment - trading restriction and price band, for their effectiveness to prevent abnormal returns and to control for volatility of the stock returns which can be attributed to the prevention of price manipulation and increase in market efficiency and integrity.

\subsection{Implications of the Study}

If the surveillance mechanism (shifting stocks to trade for trade segment) is effective, it benefits to the investors in terms of better price discovery, to the companies in terms of more accurate company valuation and to the exchanges in terms of high investor and company confidence.

Further, surveillance departments are cost centres for the exchanges. Knowing how the costs of surveillance facilitate the benefits of trading activity and the like has been a fundamental question for market integrity and the operation of an exchange (Aitken, Mike and Siow-2003). Cumming and Johan (2008) argue that the investor's confidence suffers the greatest harm when investors lose money and think that the exchange is to blame for the manipulation. Therefore the exchanges have a financial interest in ensuring the integrity of their markets to attract new listings and trading activity. Thus this study has major implications not only for the investors and companies but also for the exchanges.

\section{Literature Review}

Surveillance action is a part of market microstructure. Market structure affects the speed and quality of price discovery, liquidity, and the cost of trading (Madhavan (2002)). O'Hara (2001) maintains that monitoring is necessary by the exchange to prevent manipulation. Investors care about the efficiency of price discovery because it influences the risk of holding stock. Optimal market design must lower execution cost and enhance price discovery. Also how well and how quickly the stock prices adjust to the fundamental values is an important metric for the exchange.

As a counter measure to the instability of the stock market, various measures were introduced by to avoid huge losses. One such solution is circuit breakers or price bands (Mukherjee - 2007). Kim and Rhee (1997) conduct an event study on price limits imposed on the individual securities on Tokyo Stock Exchange. They examine three hypotheses against the benefits of having price limits. Volatility spill over hypothesis, which argue that the price limits instead of reducing volatility merely causes the volatility to spread over to subsequent periods. Delayed price discovery hypothesis, which contends that the price limits stop stocks from reaching the true equilibrium price for that day, thus causing a delay in the price discovery process; and trading interference hypothesis, which establishes that the price limits drastically reduces the liquidity of the particular stock on the event day, causing liquidity to increase substantially in the subsequent periods, thereby interfering in the trading.

Kenneth Kim (2001) study the relationship between price limits and stock market volatility on the stock listed on Taiwan Stock Exchange. In contradiction to the view of the most regulators, they find that when price limits are made more restrictive stock market volatility is usually not lower and vice versa. 
Ma and Chen (1994) study the effects of various corrective treatments as a part of surveillance effort of Taiwan stock exchange. Corrective treatments include trading halts, call trading and full payment / delivery with order. Trading restrictions of trade for trade segment, not allowing netting off to the traders is similar to requiring full payment or delivery with buy or sells order respectively. They find that the corrective measures taken after the consecutive warnings are able to reduce the volatility, the abnormal returns and the liquidity of the stocks. Nath (2003) finds that as stock prices approach near to their lower (and not upper) price limit there is an acceleration of trading activity.

Though, the criteria for shifting securities to trade for trade segment are not in public domain, the circulars announcing the shift which are published by National Stock Exchange of India mention that this action is taken with a view to ensure the market safety and to safeguard the interest of investors. Cumming and Johan (2008) contend that market surveillance is shrouded in secrecy by many exchanges. The often cited reason for this opaqueness is to refrain from giving would-be market manipulators inspiration or ideas that might allow them to work the system to avoid detection. However, because trade for trade segment relates to trading restrictions one can infer that trade based manipulation (also known as circular / synchronized trading) would have motivated exchanges to shift the stocks to trade for trade segment.

Allen and Gale (1992) classify stock price manipulation into three categories. They are, first, action based manipulation which is based on certain actions to change the actual or perceived value of an asset. For example, short selling. Second, information based trading which is based on spreading false information. Third, trade based manipulation simply by buying and selling. When a trader tries to buy a stock, he drives up the price. When he tries to sell it, he drives down the price. In case of circular trading, the market players buy and sell shares frequently among themselves to push up the stock price.

Jarrow (1992) shows that profitable speculation is possible if there is "price momentum,", so that an increase in price caused by the speculator's trade at one date tends to increase prices at future dates. Also profitable manipulation is possible if the speculator can corner the market. However, Allen and Gale (1992) argue that profitable price manipulation is possible, even if there is no price momentum and no possibility of a corner. In case of trade based manipulation, the manipulator does not have an informational advantage over other investors about the returns to the stock. However, the investors are uncertain whether a large trader who buys the share does so because he knows it is undervalued or because he intends to manipulate the price. It is this uncertainty that allows manipulation to be profitable.

Trade based manipulation is done with the intention of increasing the volume and consequently the price of the security. The retail investors, who trade on momentum, enter the market when volumes are high assuming that the momentum will continue; for high volumes are perceived to mean higher market interest and therefore higher prices. Karpoff (1987) argue that there is positive correlation between higher volumes and positive price change. However, if the increase in price and volume is as result of trade based manipulation, the retail investors will realize the negative return. Thus the manipulator would earn abnormal returns at the cost of the other participants.

\section{Research Gaps and Research Objectives}

\subsection{Research Gaps}

When securities are shifted to trade for trade segment with 5\% price bands, selling / buying of shares in that scrip results into giving / taking delivery of shares at the gross level and no intraday netting off facility is permitted. Thus trade for trade segment is related with trading restriction as well as price bands. Prior research has been done for analysing the impact of price bands on Indian and foreign markets (Kim and Rhee (1997) Kennerh Kim (2001) and Nath (2003)). However, trade for trade segment also involves an additional characteristic of trading restriction. We find no research examining the impact of shifting securities to trade for trade segment.

\subsection{Research Objectives}

Objective of this study is to examine the announcement effect of shifting securities to trade for trade segment on stocks returns and volatility of the stocks returns using event study methodology.

\section{Formulation of Hypotheses}

\subsection{Impact of Announcement on Stock Returns}

$\mathrm{H}_{1}$ : Announcement of securities being shifted to trade for trade segment from rolling segment has no impact on stock returns.

In case of rolling settlement, the traders can sell the security bought on the same day and trades are settled considering the net obligation, which offers an opportunity for intra - day trading. Also, buying and selling large quantity of the 
stock may not entail high cash outlay because the traders are allowed for netting of buys and sells made during the day. This provides an ideal opportunity to the manipulators to increase the volume and the price and thereby making abnormal returns.

When such stocks are shifted to the trade for trade segment, each transaction is treated separately and intraday trades are not possible. All traders, including those who indulge in trade based manipulation will have to pay for the total purchases and also deliver the securities which are sold without netting off. The large cash/security outlay is expected to deter traders from engaging in trade based manipulations.

If the surveillance action in the form of shifting trades to trade for trade segment is not effective to prevent the manipulation, there would be no impact on returns of the stocks after they are shifted to trade for trade segment.

Ma and Chen (1994) argue that a warming announcement provides information to the public and signals to the participants in abnormal trading activity that the regulatory authority has noticed this situation. One would therefore expect the warming announcements to enhance efficiency of the market. Accordingly, the announcement of surveillance action to be taken should be able to eliminate or even negate the excess return on the abnormally traded stock.

Thus we expect that announcement of securities being shifted to trade for trade segment from rolling segment has negative impact on stock returns.

\subsection{Impact of Announcement on Volatility of Stock Returns}

$\mathrm{H}_{2}$ : Announcement of securities being shifted to trade for trade segment from rolling segment has no impact on the volatility of the stock returns.

The second element of trade for trade segment is 5\% price bands imposed on the stocks. Price bands are imposed to reduce the volatility of the stock returns. However, Kim and Rhee (1997), Kim (2000) argue that price bands rather than decreasing volatility, increase volatility or spills over the volatility over the subsequent trading days. Nath (2005) finds that there was volatility spill over to stocks subject to narrow price band rules, and for upward moves. Further, as trading is restricted in the securities shifted to trade for trade segment; we expect that shifting securities to trade for trade segment increases volatility.

Thus we expect that announcement of securities being shifted to trade for trade segment from rolling segment increases the volatility of the stock returns.

\section{Research Methodology and Data}

\subsection{Research Methodology}

The impact of moving a stock to trade for trade segment is measured using a standard event study methodology as described in Brown and Warner (1985). Consistent with Brown and Warner (1985) we estimate the following market model to measure abnormal returns in the short run.

$$
R_{i t}=\alpha_{i}+\beta_{i} R_{m t}+\varepsilon_{i t}
$$

$$
\text { Where, } E\left(\varepsilon_{i t}\right)=0 \text { amd } \operatorname{Var}\left(\left(\varepsilon_{i t}\right)=\sigma_{\varepsilon i}^{2}\right.
$$

$R_{i t}$ and $R_{m t}$ are the period $t$ returns on security $i$ which is shifted to trade for trade segment and the market portfolio $m$ respectively. $\alpha_{i}$ and $\beta_{i}$ are the parameters of market model. CNX 500 index from National Stock Exchange of India has been used as the benchmark market portfolio return to control for the broad market movements while measuring price effects.

For estimating the market model we use a 200 day estimation window starting from $t=-230$ to $t=-31$ where $\tau$ is the event date or announcement date. Also, defining a precise event window is essential for making the event study methodology meaningful. The event window in this study ranges from a 3 day event window (day -1 to day +1 ) to a 61 day event window $(-30$ to +30$)$. Taking such longer event windows would help in assessing the robustness of the results as they would help in accounting for leakage of information to the market. In order to investigate if bulk trades generate any abnormal returns for a stock on each day $t$ in the event period, the actual returns in the event window are compared with the market model predicted returns of that stock in the event window. The abnormal return for each stock is found by subtracting the benchmark return from the market model computed returns. It is computed as follows.

$$
A R_{i t}=R_{i t}-\left(\widehat{\alpha}_{\imath}+\widehat{\beta}_{l} R_{m t}\right)
$$


In the above equation $\hat{\alpha}_{i}$ and $\hat{\beta}_{i}$ are ordinary least squares estimates from the estimation period using the market model. $R_{i t}$ and $R_{m t}$ are the returns (ex post returns) of the security $i$ and the market portfolio $m$ respectively for period $t$ in the event window. In order to make statistical inferences average abnormal returns (AAR) and cumulative average abnormal returns (CAAR) are calculated as follows.

$$
A A R_{t}=\frac{1}{n} \sum_{i=1}^{N} A R_{i t}
$$

Where $\mathrm{n}$ is the number of stocks whose abnormal returns are available on day $t$ in the event window. By cumulating the periodic average abnormal return over a particular time interval (t period around the event date), we obtain the cumulative average abnormal returns (CAAR).

$$
C A A R_{k}=\sum_{t=1}^{k} A A R_{t}
$$

Where, $\mathrm{t}$ will take values from -10 to +10 . All abnormal returns are standardized to compute the $\mathrm{t}$-statistics.

$$
S A R_{i t}=\frac{A R_{i t}}{S_{i}(A R)}
$$

Where, $\mathrm{S}_{\mathrm{i}}(\mathrm{AR})$ is the standard deviation of the abnormal returns of stock ' $\mathrm{i}$ ' in the estimation period. The $t$-statistic for the sample of $\mathrm{n}$ stock for each day $\mathrm{t}$ in the event window is calculated as follows.

$$
t\left(S A R_{i t}\right)=\left(\sum_{i=1}^{n} S A R_{i t}\right) \frac{1}{\sqrt{n}}
$$

Following Amihud and Mendelson (1987) volatility has been measured by taking square of daily close to close returns. It is calculated as follows.

$$
\mathrm{V}_{\mathrm{tj}}=\left(\mathrm{r}_{\mathrm{tj}}\right)^{2}
$$

Where, $r_{t j}$ denotes the daily return for each stock $j$ on Day $t . V_{t j}$ has been calculated for 30 days prior and 30 days after the event day for each stock. A paired t-test is employed between both the groups (pre and post event days) to examine for the difference in the volatility.

\subsection{Data}

All the securities which were shifted to trade for trade segment on NSE from 1st January 2004 to 31st December 2009 are considered. Data for announcement of securities in to trade for trade segment is taken from NSE website. Adjusted closing prices of these securities are obtained from Prowess maintained by Centre for Monitoring Indian Economy.

\section{Empirical Results}

\subsection{Descriptive Statistics}

The following tables present the descriptive statistics for 899 stocks as on the event day and as on the $10^{\text {th }}$ day before and after the event day. Variables considered are market capitalisation (M. Cap), and volume.

Table 1. Descriptive Statistics as on the $10^{\text {th }}$ Day before the Event Day, as on the Event Day and $10^{\text {th }}$ Day after the Event Day. (All figures are expressed in Rupees in Million.)

\begin{tabular}{lllllll}
\hline & \multicolumn{2}{l}{ 10th Day Before the Event } & Event Day & & \multicolumn{2}{l}{ 10th Day After the Event } \\
\hline & M. Cap & Volume & M. Cap & Volume & M. Cap & Volume \\
\hline n & 899 & 899 & 899 & 899 & 899 & 899 \\
Mean & 1456.07 & 1.56 & 1519.52 & 13.13 & 1381.76 & 8.11 \\
Min & 21.06 & 0 & 24.51 & 0 & 21.75 & 0 \\
Max & 60006.36 & 42.24 & 70046.51 & 3827.36 & 59111.53 & 691.35 \\
Std & 2991.3 & 3.625 & 3489.32 & 117.82 & 3677.01 & 33.1 \\
\hline
\end{tabular}

A comparative study of market capitalization between the three days reveals that its mean value is increasing as it approaches to the event day from Rs. 1456.07 million on $10^{\text {th }}$ day before the event to Rs. 1519.52 million. Also its mean 
value decreases after the event day to Rs.1381.76 million during the 10 day period post event. There is constant increase of standard deviation from during the pre and post event period. However, the event has approximately restored its minimum and maximum value which was Rs.21.06 million and Rs.60006.36 million.

Similarly, there is an increase in mean value of volume from Rs. 1.56 million as on the $10^{\text {th }}$ day before the event day to Rs.13.13 million as on the event day. However the event seems to be negatively impacting the volume which is 8.11 as on the $10^{\text {th }}$ day after the event day. Minimum volume is zero as some stock may not get traded on a particular day during the same period. The maximum volume has increased from Rs.42.42 million to Rs.3827.36 million and again decreased to Rs.691.35 million during these days. Also standard deviation follows the similar pattern; increase till the event day and decrease till the $10^{\text {th }}$ day post event.

The analysis of descriptive statistics for these three days indicates the negative impact of the announcement on the market capitalisation and volume.

\subsection{Results of Event Study Methodology}

After calculating Average Abnormal Returns and Cumulative Average Abnormal Returns of these stocks t-statistics have been calculated. Table 2 summarises the results.

Table 2. Average Abnormal Returns of the Securities shifted to Trade for Trade Segment.

\begin{tabular}{|c|c|c|}
\hline Day & Average Abnormal Returns in \% & t-Stat \\
\hline$(-10,-10)$ & 1.48 & $11.02 * *$ \\
\hline$(-9,-9)$ & 1.34 & $10.01 * *$ \\
\hline$(-8,-8)$ & 1.27 & $9.27 * *$ \\
\hline$(-7,-7)$ & 1.57 & $11.93 * *$ \\
\hline$(-6,-6)$ & 1.58 & $11.21 * *$ \\
\hline$(-5,-5)$ & 2.71 & $18.82^{* *}$ \\
\hline$(-4,-4)$ & 2.15 & $15.15^{* *}$ \\
\hline$(-3,-3)$ & 2.48 & $16.81^{* *}$ \\
\hline$(-2,-2)$ & 2.66 & $17.51 * *$ \\
\hline$(-1,-1)$ & 2.00 & $13.57 * *$ \\
\hline$(0,0)$ & 0.45 & $3.32 * *$ \\
\hline$(1,1)$ & -1.23 & $-10.17 * *$ \\
\hline$(2,2)$ & -0.52 & $-4.62 * *$ \\
\hline$(3,3)$ & -0.32 & $-2.97 * *$ \\
\hline$(4,4)$ & -0.96 & $-9.58 * *$ \\
\hline$(5,5)$ & -0.59 & $-5.76^{* *}$ \\
\hline$(6,6)$ & -0.39 & $-4.18 * *$ \\
\hline$(7,7)$ & -0.35 & $-3.71 * *$ \\
\hline$(8,8)$ & -0.11 & -1.20 \\
\hline$(9,9)$ & -0.37 & $-4.02 * *$ \\
\hline$(10,10)$ & -0.14 & -1.50 \\
\hline$(-30,-1)$ & 25.46 & $33.65^{* *}$ \\
\hline$(-10,-1)$ & 19.23 & $40.29 * *$ \\
\hline$(-10,10)$ & 14.70 & $22.94 * *$ \\
\hline$(1,10)$ & -4.97 & $-12.96^{* *}$ \\
\hline$(1,30)$ & -5.83 & $-8.16 * *$ \\
\hline$(-30,30)$ & 19.99 & $18.31 * *$ \\
\hline
\end{tabular}

Note: $* *, *$ and ${ }^{\text {a }}$ represent significance levels of $1 \%, 5 \%$ and $10 \%$ respectively. 
The above results indicate that there is significant positive average abnormal return on the stocks before they are shifted to trade for trade segment. During the 10 days and 30 days period before the event day, the Average Abnormal Returns generated is $19.23 \%$ and $25.46 \%$ respectively which is significant at less than $1 \%$ level. As on the event day there is $0.45 \%$ Average Abnormal Returns generated which is significant at less than 5\% level. Also, there is significant negative Average Abnormal Returns on the stocks from day 1 to day 30. It is negative $4.97 \%$ and negative $5.83 \%$ during 10 days and 30 days period respectively.



Diagram 1. Average Abnormal Returns and Cumulative Average Abnormal Returns of the Securities shifted to Trade for Trade Segment

The above diagram shows the movement of Average Abnormal Returns and Cumulative Average Abnormal Returns during the 21 day event window.

\subsubsection{Impact of Announcement on Stock Returns}

Increase in positive abnormal returns during the pre-event period and having negative abnormal returns during the post event period is in line with our analysis of market capitalisation and volume in section 8.1. We reject null hypothesis 1 and conclude that the impact of announcement of shifting securities to trade for trade segment is negative on the stocks returns. The result is in line with our expectation.

\subsubsection{Impact of Announcement on Volatility of Stock Returns}

The mean volatility during 30 days in the pre event period is found to be $0.1255 \%$ and it is $0.2853 \%$ during 30 days in the post event period. The difference is significant at less than $1 \%$ level. Thus the volatility is found to be increased post event. We reject null hypothesis 2 and conclude that announcement of securities being shifted to trade for trade segment from rolling segment increases the volatility of the stock returns. The result is in line with our expectation. 


\section{Salient Findings and Conclusions}

We examine the effectiveness of trade for trade segment as a surveillance effort to prevent price manipulation in India. The exchanges in India shift these stocks to trade for trade segment when they observe unwanted growth in the price. We observe that there is significant gain in the prices during 10 days before the event day, showing cumulative average abnormal returns of $19.23 \%$ till one day before the event day. However, there is negative reaction in terms of stocks returns from day 1 to 10.These securities experience negative cumulative average abnormal returns of $4.974 \%$ till $10^{\text {th }}$ day after the shift. Also, the price band imposed on the securities is not able to control the volatility of the stock returns as volatility increases after the announcement.

The objective of shifting securities to trade for trade segment is to ensure market safety and safeguard the interest of the investors by improving efficiency of the market. It can be broadly concluded that though trade for trade segment is not successful in controlling the volatility of stock returns, the positive abnormal returns, which can be attributed to trade based manipulation, have been negated after the event day. Thus, trade for trade segment is partially successful in improving the integrity and efficiency of the stock market.

\section{Limitations of the Study and Avenues for Further Research}

We did not examine the impact of the announcement to shift securities to trade for trade segment from rolling settlement on stocks' liquidity. Further, we did not analyse the impact of the announcement to shift securities to rolling settlement from trade for trade segment on stocks returns and volatility of stocks returns. This may bring more insights and improve our understanding on the subject.

\section{References}

Allen, F. and Gale, D. (1992). Stock-Price Manipulation. The Review of Financial Studies, 5(3), 503-529. https://doi.org/10.1093/rfs/5.3.503

Amihud, Y., \& Mendelson, H. (1987). Trading Mechanisms and Stock Returns: An Empirical Investigation. The Journal of Finance, 42(3), 533-553.https://doi.org/10.1111/j.1540-6261.1987.tb04567.x

Bowman, R. G. (1983). Understanding and conducting event studies. Journal of Business Finance \& Accounting, 10, 4. https://doi.org/10.1111/j.1468-5957.1983.tb00453.x

Cumming, D. \& Johan, S. (2008). Global Market Surveillance. Oxford University Press on behalf of the American Law and Economics Association. https://doi.org/10.1093/aler/ahn009

Harris, L. E. (1997). Circuit breakers and program trading limits: What have we learned? Brookings-Wharton Papers on Financial Services, 63.http://www-bcf.usc.edu/ lharris/ACROBAT/circuit.pdf

Jarrow, R. A. (1992). Market Manipulation, Bubbles Corners and Short Squeezes. Journal of Financial and Quantitative Analysis, 27(03), 311-336.https://doi.org/10.2307/2331322

Karpof, J. M. (1987) The Relation between Price Changes and Trading Volume A Survey. Journal of Financial and Quantitative

Analysis,

22(I).https://www.cambridge.org/core/journals/journal-of-financial-and-quantitative-analysis/article/the-relation -between-price-changes-and-trading-volume-a-survey/DBE2C70FA41E390EB8FA418BBFFD76C8

Kim, K. A. (2001). Price limits and stock market volatility. Economics Letters, 71, 131-136.https://doi.org/10.1111/j.1540-6261.1997.tb04827.x

Kim, K. A. \& Rhee S. G. (1997). Price Limit Performance: Evidence from the Tokyo Stock Exchange. The Journal of Finance, LII(2).http://www.coba.unr.edu/faculty/liuc/files/RUC/topic_pricelimit/Kim_Rhee_1997.pdf

Ma, T., \& Chen, H. J. (1994). Stock market surveillance and market performance: The case of Taiwan. Asia Pacific Journal of Management, 11(2), 305-325. https://doi.org/10.1007/BF01739205

Madhavan, A. (2002). Market microstructure: A practitioner's guide. Financial Analysts Journal, 58(5), 28-42. https://doi.org/10.2469/faj.v58.n5.2466

Mike, A. and Siow, A. (2003). Ranking World Equity Markets on the Basis of Market Efficiency and Integrity. Hewlett-Packard Handbook of World Stock, Derivative \& Commodity Exchanges, XLIX-LV/http://papers.ssrn.com/sol3/papers.cfm?abstract_id=490462

Mukherjee, D. (2007). Comparative Analysis of Indian Stock Market with International Markets.Great Lakes Herald, 1(1).http://www.greatlakes.edu.in/pdf 
Nath, P. (2003). Do price limits behave like magnets? Available at SSRN 565482.https://doi.org/10.2139/ssrn.565482

Nath, P. (2005). Are price limits always bad? Journal of Emerging Market Finance, 4(3), 281-313/http://emf.sagepub.com/content/4/3/281.abstract

O'Hara, M. (2001) Designing markets for developing countries. International review of finance, 2(4), 205-215.http://webcache.googleusercontent.com/search?q=cache:bCvlrjx

\section{Note}

Note 1. Reasons behind the shifting securities to trade for tradesegment is given in Annexure-I

\section{Annexure-I}

Why securities are shifted to trade for trade segment? (www.nseindia.com and www.bseindia.com )

Because of the following two reasons securities are traded in trade for trade segment.

- Failure of the companies to established connectivity with both the depositories as per Securities and Exchange Board of India (SEBI) directive. The list of these securities is notified by SEBI from time to time and

- On account of surveillance action by the stock exchange

SEBI has mandated that trading and settlement in all listed securities would take place only in Compulsory Rolling Settlement (CRS). Further, it has directed all companies to sign agreements and establish connectivity with both the depositories (NSDL and CDSL) latest by September 30, 2001. SEBI has further mandated that the trading and settlement in securities of those companies which have failed to make the required dematerialization arrangements by the above stipulated date, be shifted to trade for trade basis. As per clause 35 of Listing Agreement, to establish the connection, at least $50 \%$ of other than promoter stock holdings must be in dematerialized form.

This also forms a part of surveillance effort of the exchanges to ensure the market safety and to safeguard the interest of the investors.

When the company establishes the connection with both the depositories, SEBI directs the stock exchanges that they (exchanges) may shift the said securities to rolling settlement again if there is no other reason for continuation of the securities in trade for trade segment.

Thus once the company establishes the connectivity with the depositories, there are a very few reasons to again to lose the connectivity. The number of outstanding shares with the public (called as free float) in dematerialized form will change by share repurchase, increase in promoter stock holdings or the like cases. Whereas the possibilities of these events occurring are rare, whenever any stock is shifted to trade for trade, it can be inferred that it is due to surveillance action and not due to connectivity issue.

Further, it is important to note that circulars/notices available at NSE and BSE websites also mention that the transfer of security trade for trade is purely on account of market surveillance. This measure is periodically reviewed to examine whether the securities can be shifted back to rolling segment. 